\title{
A szexuális funkciózavar és a metabolikus szindróma kapcsolata
}

\author{
Zsoldos Márta ${ }^{1}$ - Pajor Attila dr. ${ }^{3}$ - Pusztafalvi Henriette dr. ${ }^{2}$ \\ ${ }^{1}$ Pécsi Tudományegyetem, Egészségtudományi Kar, Egészségtudományi Doktori Iskola, Pécs \\ ${ }^{2}$ Pécsi Tudományegyetem, Egészségtudományi Kar, Egészségfejlesztési és Népegészségtani Tanszék, Pécs \\ ${ }^{3}$ Semmelweis Egyetem, Általános Orvostudományi Kar, II. Szülészeti és Nőgyógyászati Klinika, Budapest
}

\begin{abstract}
Az utóbbi évtizedekben a metabolikus szindróma, a 2-es típusú diabetes, a cardiovascularis betegségek, az elhízás és a depresszió gyakorisága megnőtt. Mivel a szexuális funkciózavar is gyakran fordul elő, az irodalmi adatok áttekintésével arra a kérdésre kerestünk választ, hogy milyen összefüggés áll fenn a szexuális funkciózavar és a metabolikus szindróma, illetve annak komponensei között. Kimutattuk, hogy a metabolikus szindróma klinikai és biokémiai komponensei - mint a cardiovascularis betegség, a 2-es típusú diabetes, a hasi elhízás és a depresszió, továbbá az inzulinrezisztencia, az atherogen dyslipidaemia, a hypogonadismus, a krónikus szisztémás gyulladás és az endothel funkciózavara - mind hátrányosan befolyásolják a szexuális funkciót. A szexuális izgalmi fázis zavara férfiakban kifejezetten és nőkben mérsékelten függ össze a cardiovascularis betegségekkel. Diabetesben a microvascularis károsodás és az autonóm neuropathia jelentősen rontja a szexuális funkciót. Az erekciós zavar és a női szexuális izgalmi reakció, illetve orgazmus zavara összefüggést mutat az inzulinrezisztenciával, az atherogen dyslipidaemiával és az elhízással járó szisztémás gyulladásos reakcióval. A szexuális funkciózavar, különösen férfiakban, korai jele lehet a metabolikus szindróma későbbi súlyos szövődményeinek. A metabolikus szindróma komponensei és a szexuális funkciózavar egyaránt helyreállítható, elsősorban az életmód megváltoztatásával.
\end{abstract} Orv Hetil. 2019; 160(3): 98-103.

Kulcsszavak: metabolikus szindróma, szexuális funkciózavar, diabetes, elhízás, cardiovascularis betegség

\section{Relation between sexual dysfunction and metabolic syndrome}

The prevalence of the metabolic syndrome, type 2 diabetes mellitus, cardiovascular diseases, obesity and depression have increased during the recent years. As the sexual dysfunction is also frequent, we aimed to search for the associations between sexual dysfunction and the metabolic syndrome and its components, respectively, by reviewing the literature. The clinical and biochemical components of the metabolic syndrome included cardiovascular disease, type 2 diabetes mellitus, visceral obesity and depression, furthermore, insulin resistance, atherogenic lipid profile, hypogonadism, chronic systemic inflammation and endothelial dysfunction were all demonstrated to affect adversely the sexual function. The dysfunction of the sexual arousal response shows a strong association in men and a milder one in women with the cardiovascular diseases and depression. Sexual function in diabetes mellitus is mostly impaired by microvascular injury, polyneuropathy and autonomic neuropathy. Erectile dysfunction and disorder of the female sexual arousal response and the orgasm, respectively, are associated with insulin resistance, atherogenic lipid profile and systemic inflammatory condition in overweight or obese patients. Sexual dysfunction particularly in men can be an early sign of the severe complications of metabolic syndrome. The pathogenetic link between the metabolic syndrome and the sexual dysfunction seems to be the insulin resistance. Both metabolic syndrome and sexual dysfunction can be restored by altering the lifestyle.

Keywords: metabolic syndrome, sexual dysfunction, diabetes mellitus, obesity, cardiovascular disease

Zsoldos M, Pajor A, Pusztafalvi H. [Relation between sexual dysfunction and metabolic syndrome]. Orv Hetil. $2019 ; 160(3): 98-103$.

(Beérkezett: 2018. július 3.; elfogadva: 2018. szeptember 11.) 


\section{Rövidítések}

1-DM = 1-es típusú diabetes mellitus; 2 -DM = 2-es típusú diabetes mellitus; $\mathrm{BMI}=($ body mass index $)$ testtömegindex; $\mathrm{CV}$ = cardiovascularis $; \mathrm{ED}=$ erekciós diszfunkció $; \mathrm{HDL}=($ highdensity lipoprotein) magas sürüségü lipoprotein; IR = inzulinrezisztencia; $\mathrm{LDL}=($ low-density lipoprotein $)$ alacsony sürüségü lipoprotein; $\mathrm{MS}=$ metabolikus szindróma; $\mathrm{TG}=$ triglicerid

Az utóbbi évtizedekben számos krónikus betegség mint a metabolikus szindróma (MS), hypertonia, koszorúér-betegség, stroke, 2 -es típusú diabetes (2-DM), elhízás, depresszió és gyulladásos betegségek - gyakorisága olyan mértékben növekedett, hogy már népegészségügyi problémát jelent. A MS alapvető összetevői az inzulinrezisztencia (IR), az atherogen dyslipidaemia, a centrális hízás és a hypertonia, de hozzátartozhat a krónikus szisztémás gyulladásos állapot, a vascularis endothel funkciózavara, a gyorsult véralvadás és a genetikai hajlam is. Az említett biokémiai és klinikai tényezők kölcsönösen hatnak egymásra [1]. A MS a 2-DM és a cardiovascularis $(\mathrm{CV})$ betegségek előfutárának tekinthető [2-4]. A fejlett országokhoz hasonlóan hazánkban a férfiak 38\%-ában és a nők 30\%-ában fordul elő [5].

Tudjuk, hogy az egyén jó életminőségéhez és kiegyensúlyozott párkapcsolatához nagyban járul hozzá az egészséges szexuális funkció. A szexuális funkció zavara, amelyet többféle biológiai, pszichológiai és szociális tényező okozhat, férfiben és nőben egyaránt gyakori problémát jelent. Tanulmányunkban az irodalmi adatok felhasználásával azt vizsgáljuk, vajon a szexuális funkciózavar hogyan függ össze a MS-val, illetve annak fő komponenseivel. A témaválasztás jelentőségét alátámasztja a MS és a szexuális funkciózavar gyakori előfordulása.

\section{Metabolikus szindróma}

Kimutatták, hogy MS-ban az adiponektin/leptin arány változásai összefüggenek a vércukorszint, az inzulinérzékenység, a koleszterinszint, a low-density lipoprotein (LDL-) szint és a szisztolés vérnyomás változásaival [6]. Magasabb leptin/adiponektin arány esetén fokozódik az angiotenzin-II hatására bekövetkező érösszehúzódás. Ez is hozzájárul a hypertonia, illetve a CV betegségek kialakulásához. Végső soron az IR a verőérhálózatban kialakult tünetmentes krónikus gyulladás révén érelmeszesedéshez vezet [7]. Termékeny korú nőknél azt tapasztalták, hogy MS esetén a szexuális funkciózavar előfordulása gyakoribb, mint az egészségeseknél, valamint a MS rizikótényezői, illetve komponensei szoros kapcsolatban állnak a szexuális funkciózavar előfordulásával, és a magas triglicerin (TG)-szint a szexuális funkciózavar független prediktora [8]. A perimenopausában lévő nókben is meghatározták a high-density lipoprotein (HDL-), LDL- és TG-szinteket, valamint kérdőíves módszerrel mérték a szexuális funkciózavart. A szexuális funkciózavar dyslipidaemia esetében, a menopausastatustól füg- getlenül, gyakoribb volt, mint ennek hiányában [9]. Egy további vizsgálat szerint a menopausában lévő, MS-ban szenvedő nők körében az egészségesekhez képest kétszer gyakoribb a szexuális funkciózavar, és a magasabb TGszint a szexuális funkciózavar magasabb kockázatával jár [10].

Egyesek összefüggést találtak a MS és az erektilis funkciózavar (ED), a MS és a hypogonadismus, valamint a MS és a női szexuális funkciózavar között, továbbá igazolták, hogy a testsúly csökkentése javítja a szexuális funkciót [11]. MS-ban szenvedő nőknél a táplálkozás megváltoztatásával és a rendszeres fizikai aktivitással csökkenthető a krónikus szubklinikai gyulladásos állapot, ezáltal javul az endothelfunkció, és egyúttal a vérnyomás, valamint a szexuális funkciózavar csökkenése is elérhető $[12,13]$. Metaanalízis szerint a táplálkozás minőségi változtatása és a fizikai aktivitás fokozása férfiaknál és nőknél egyaránt kedvezően befolyásolja a MS-át és a szexuális funkciót $[1,14]$.

\section{Cardiovascularis betegségek}

A világ felnőtt lakosságának hozzávetőleg egynegyede szenved hypertoniában. A hypertonia magas kockázatot jelent a 2-DM, az elhízás és a szexuális funkciózavar kialakulására, továbbá 2-DM-ban a társuló hypertonia, különösen az elhízással együtt, mindkét nemben rontja a szexuális funkciót [15]. Az egészségesekhez képest a CV betegek körében kétszer gyakrabban figyeltek meg szexuális funkciózavart, azaz a nemi vágy csökkenését, a nemi egyesülés során a hüvely szárazságát és fájdalmát, az erotikus, illetve genitális ingerekre adott csökkent reakciót és az orgazmus zavarát [16]. A szívbetegek közel felénél legalább egyféle szexuális probléma áll fenn, például az ED 33\%-ban, a szexuális érdeklődés hiánya pedig 10\%-ban mutatható ki [17]. Férfiaknál a szexuális funkcióban észlelt zavarok már évekkel megelőzhetik a szívroham jelentkezését. Ez arra utal, hogy a szexuális funkciózavar megjelenése elöre jelezheti a CV betegség bekövetkezését [18]. A férfiaktól eltérően nőknél még nem eléggé feltárt a szexuális funkciózavar és a $\mathrm{CV}$ betegségek közötti kapcsolat, bár vannak arra utaló bizonyítékok, hogy a MS-val járó endothelfunkció-zavar a női genitális szövetekben is okozhat véráramlási elégtelenséget [19]. Egy legutóbbi prospektív vizsgálat a CV betegség és a szexuális funkciózavar összefüggését mind a két nemnél igazolta [20]. Mindenesetre a rendszeres sportolás javítja a MS biokémiai komponenseit, ezáltal segíti a szívbetegeket abban, hogy visszatérjenek a szexuális aktivitásba, annál is inkább, mert a fizikai aktivitás növelése helyreállíthatja az ED-t és a csökkent libidót [4, 13].

\section{Diabetes}

A 2-DM fennállása esetén a libido csökken, az erektilis funkció és az ejakuláció romlik, valamint pszichés zavar és depresszió is kialakulhat. A szexuális funkcióra gyako- 
rolt hátrányos hatás elsősorban a metabolikus zavarnak, az idegkárosodásnak és az érrendszeri elváltozásoknak, valamint az alacsony tesztoszteronszintnek tudható be [21]. Maga a polineuropathia a hyperglykaemia, a metabolikus zavar és a microvascularis eltérések következménye. A 2-DM-ban kialakulhat autonóm neuropathia is [22]. Az idegvezetés rejtett funkcionális károsodása sokszor már a polineuropathia felismerése előtt következik be [23]. Az autonóm idegrendszer károsodásának leggyakoribb és legkorábbi jele a cardialis autonóm neuropathia. A női szexuális zavarok és a cardialis neuropathia között szoros kapcsolatot igazoltak 1-DM-ban [24]. Nőknél 2-DM esetén 25,6\%-ban mutattak ki szexuális funkciózavart [25]. Férfiaknál pedig a CV neuropathia megjelenése több mint kétszeresére növeli az ED előfordulását [26]. 1-DM-ban az ED 10-15 évvel korábban jelentkezik, mint az egészségesekben, és az ED a magas hemoglobin-A-lc $\left(\mathrm{HbA}_{\mathrm{lc}}\right)$-értékkel mutat szoros kapcsolatot. A vércukorszint megfelelő szabályozása viszont csökkenti a 10 évvel később jelentkező ED előfordulását, különösen a microvascularis szövődményekkel bíró férfiakban [27]. 2-DM-ban akkor a legmagasabb a koszorúér-betegség és szexuális funkciózavar kockázata, ha egyidejűleg hypertonia és elhízás is fennáll [15]. A 2-DM-ban szenvedő férfiak nyomon követése során kimutatták, hogy az életkor, az inzulinkezelés, a 8,0\% feletti $\mathrm{HbA}_{\mathrm{lc}}$ szint, a 3,88 mmol/l-nél magasabb összkoleszterinszint és a depressziós tünetek súlyossága képezik az ED prediktorát. Az ED legalacsonyabb kockázatát a depressziós tünetek alacsony szintje és a $\mathrm{HbA}_{\mathrm{lc}} 8,0 \%$ alatti értéke képezte [28].

\section{Elhízás}

Tudjuk, hogy a MS, a 2-DM és az elhízás kölcsönösen átfedik egymást. Az elhízás már serdülőkorban növeli a MS és a CV betegség kockázatát [6]. A hasi (visceralis) elhízás esetén a zsírszövet csökkent mértékben termeli a gyulladásellenes, 2-DM-ellenes és az antiatherogen hormont, az adiponektint, és fokozza a gyulladásos citokinek (tumornekrózisfaktor- $\alpha$, interleukin-6, interleukin-1) felszabadulását előidéző leptin termelését. A leptin/adiponektin arány eltolódása tüneteket nem okozó gyulladásos állapotot vált ki, amely IR-val és endothelfunkció-zavarral társul [13, 29]. Megfigyelték, hogy a túlsúlyos és elhízott betegeknél a szexuális zavar gyakoribb, mint a soványakban, és a testtömegindex (BMI) növekedésével a zavar fokozódik [30, 31]. Ennek hátterében neurobiológiai, hormonális, vascularis és mentális zavar állhat. Nőknél a BMI növekedésével csökken az orgazmus és a szexuális kielégülés aránya [32], továbbá a derék-csípő körfogat arányának növekedésével általában gyakoribbá válik a női szexuális funkciózavar [33]. A BMI növekedése gátolja a szexuális izgalmi fázis kialakulását, a hüvely nedvesedését, az orgazmust és a kielégülést, de nincs hatással a szexuális vágyra és a közösülési fájdalomra. Elhízott betegekben a MS komplex kezelésével csökkenthető a krónikus gyulladásos állapot és a $\mathrm{CV}$ betegség kockázata [6].

\section{Férfiakban előforduló szexuális funkciózavar}

Férfiakban a leggyakoribb szexuális funkciózavar az ED. Az IR és a MS esetében a szabad tesztoszteronszint csökkenhet, és a hypogonadismus hozzájárul a férfi szexuális funkciózavarához [21]. Egy vizsgálat szerint a férfiak 16,1\%-ában alacsony a tesztoszteronszint, 31,3\%ában MS mutatható ki, továbbá 20\%-a szenved ED-ben. Az ED prediktorát az emelkedett éhgyomri vércukorszint, a hypertonia, az alacsony HDL-szint és a szívbetegség képezték. Egyébként a MS valamennyi összetevője független kapcsolatot mutatott a tesztoszteronhiány-szindrómával [34]. Mások a férfiak 61,3\%-ában találtak MS-át, és ezekben az esetekben $85,5 \%$-ban fordult elő kérdőíves módszerrel feltárt ED. A MS összefüggést mutatott a csökkent szexuális vággyal, az alacsony szérum-tesztoszteronszinttel, a magas interleukin-6- és Creaktívprotein-szintekkel. A MS összetevői közül azonban az éhgyomri vércukorszint mutatta a legerôsebb összefüggést az ED-vel [35]. Egy munkacsoport a MSval társult ED-ban szenvedők 70,3\%-ában igazolta a pénisz cavernosus artériájának csökkent véráramlását és 59,3\%-ukban a szisztémás érrendszer kóros állapotát [36]. Más kutatók is megállapították Doppler-ultrahangvizsgálattal, hogy az ED-ban szenvedő férfiak felében az ED vascularis eredetü [37]. Ezekben a betegekben a pénisz cavernosus artériájának fala megvastagodott, és egyúttal a nyaki artériában is kimutatható volt a véráramlás csökkenése. Mivel a pénisz artériája vékonyabb a koszorúereknél, a szisztémás érkárosodás korábban vezet EDhoz, mint más CV betegséghez [38]. Az ED, a CV betegségek és a MS rizikótényezői megegyeznek egymással, és a MS komponensei közül a hasi elhízás látszik az ED fó kockázati tényezőjének [31]. Megfigyelték, hogy a MS kezelésével emelkedik a tesztoszteronszint, csökken az IR, és csökken az ED mértéke is [39].

\section{Női szexuális funkciózavar}

Összefoglaló tanulmányok szerint a MS hátrányosan befolyásolja a női szexuális funkciót $[3,40]$. A praemenopausában lévő nők 43,1\%-ában a szexuális funkció valamelyik területén probléma fordul elő, de az ezzel kapcsolatos aggodalom, illetve a szexuális élet minőségromlásának megélése csak 22,2\%-ban igazolható [41]. Menopausában lévő szexuálisan aktív nőkben szûrôvizsgálattal 39,8\%-ban találtak MS-t. A MS-ban szenvedők 52,9\%-ában elhízás, 35,4\%-ában hypertonia, 55,8\%-ában magas TG, 17,5\%-ában hyperglykaemia, 59,7\%-ában csökkent HDL-szint volt kimutatható. Az említett MS- 
komponensek közül a hyperglykaemia és a csökkent libido között találtak szoros összefüggést [42]. Ismert, hogy az erotikus/szexuális ingerek hatására kialakuló női szexuális válaszkészség első szakaszát neuromuscularis és vasocongestiv folyamatok szabályozzák, amelyek miatt a csikló és a kisajkak tömege 2-3-szorosára növekszik a vértódulás következtében. A csikló artériájában a Doppler-ultrahangvizsgálattal mért véráramlás-csökkenés pozitív összefüggést mutat a MS-val, különösen az IR-val, továbbá a BMI-vel, a derékkörfogattal, a TG-del, a csökkent szexuális izgalmi válaszkészséggel és a szorongás tüneteivel [43]. Kimutatták, hogy a túlsúlyos és elhízott nókben mind a csikló, mind a szemartéria véráramlása csökken a soványakhoz képest, ami arra utal, hogy az elhízás a nemi szerv és az általános verőérhálózat rugalmatlanságával jár együtt [44]. Ebből a vizsgálatból az is kiderült, hogy az elhízás mértékének növekedésével arányosan csökken a heti szexuális együttlétek száma, és gyakoribbá válik az orgazmus hiánya. Menopausában az ösztrogénhiány és a szimpatikus túlsúly segíti elő az IR kialakulását. Egy kutatócsoport szerint az átlagosan 73 éves korú nők 39\%-a szexuálisan aktív, és 41,5\%-a MSban szenved. A MS komponensei - mint a magas $\mathrm{HbA}_{1 c^{-}}$ szint, a 2-DM, a hypertonia, a hasi elhízás, a magas TGszint és a koszorúér-betegség - szoros összefüggést mutattak a szexuális funkciózavarral [45]. Legutóbb egy nagy esetszámú prospektív vizsgálat is igazolta a szexuális izgalmi válasz nehézsége és a $\mathrm{CV}$ betegség között fennálló kapcsolatot [20]. Egy összefoglaló tanulmány szerint a MS-val kapcsolatos endothelfunkció-zavar befolyásolhatja ugyan a genitális szövetek vérellátását, de a CV kockázati tényezők és a szexuális funkció közötti öszszefüggést az epidemiológiai vizsgálatok nőkben gyengébbnek találták, mint férfiakban [19].

\section{Depresszió}

A depresszió, illetve a depressziós hangulat és a MS szoros kapcsolatban állnak egymással [2]. A depresszió tüneteihez hozzátartozik a motiválatlanság és a csökkent libido. 2-DM-ban a depressziós tünetek magas szintje az ED kockázatát a háromszorosára növeli [28]. A szexuális vágy, izgalmi állapot vagy orgazmus zavarával küzdő nők 40\%-a egyúttal depressziós is [46]. Nagy esetszámú prospektív vizsgálat igazolta, hogy a szexuális funkciózavar férfiaknál és nőknél egyaránt összefüggésben áll a depresszióval [20].

\section{Patogenetikai kapcsolat}

Az évekig vagy évtizedekig tünetmentes IR előbb-utóbb MS-hoz vezet. A MS az anyagcsere hatásai, a vascularis, endokrin, idegkárosító és a gyulladásos reakciója révén nemcsak a hypertonia, illetve CV betegségek, 2-DM, depresszió és elhízás kialakulásához, hanem mindkét nemben szexuális funkciózavarokhoz is vezethet. Ezek a kórképek gyakoriak és sokszor átfedik egymást. Ezáltal a szexuális funkciózavar az egészségi állapot egyik jelzőjének tekinthetô férfiakban, ami nókben is valószínú, de egyértelmúen még nem bizonyított. A CV betegségek, a depresszió, a 2-DM, az elhízás és a csökkent libido, valamint az ED között, továbbá nőkben az erotikus/szexuális ingerekre bekövetkező szexuális izgalmi állapot elégtelensége, illetve az orgazmuszavar között az IR, illetve a MS képezi a patofiziológiai kapcsolatot. A MS olyan komponensei, mint CV betegségek, hypogonadismus, elhízás és depresszió, pszichoszociális faktorokon keresztül mindkét nemben további negatív hatást fejtenek ki a szexuális funkcióra $[8,16,28]$. Megfigyelések szerint a MS komplex kezelése, elsősorban a táplálkozás helyes beállítása, a fizikai aktivitás fokozása és a stressz oldása megállítja vagy helyreállíthatja a patofiziológiai folyamatokat, ezáltal a párkapcsolatokra kihívást jelentő, mindkét nemet érintő szexuális funkciózavar is javul [1, 3, 4, $13,14,21]$.

\section{Következtetés}

A MS diagnosztizálása kapcsán szexuális funkciózavar egyidejű fennállására vagy későbbi megjelenésére lehet számítani. A MS klinikai és biokémiai komponensei egyaránt hátrányosan befolyásolják a szexuális egészséget. A szexuális funkciózavarok megjelenése gyakran társul a MS-val, és korai jele lehet a súlyos cardiovascularis betegségnek vagy a 2-DM-nak. Mindez aláhúzza az IR, illetve a MS szûréssel történő kimutatásának fontosságát és a MS elsősorban életmód-változtatással történő kezelését.

Anyagi támogatás: A közlemény megírása anyagi támogatásban nem részesült.

Szerzői munkamegosztás: A kézirat megírásában és az irodalom összeállításában minden szerző részt vett. Zs. M., P. A.: Az irodalom elkészítése. Zs. M., P. A., P. H.: A kézirat megírása és szerkesztése. A cikk végleges változatát valamennyi szerző elolvasta, jóváhagyta.

Érdekeltségek: A szerzőknek nincsenek érdekeltségeik.

\section{Irodalom}

[1] Kaur J. A comprehensive review on metabolic syndrome. Cardiol Res Pract. 2014; 2014: 943162.

[2] Halmos T, Suba I. Association of depression with type 2 diabetes and metabolic syndrome. [A depresszió kapcsolata a 2-es típusú diabétesszel és a metabolikus szindrómával.] Magy Tud. 2009; 170: 1118-1119. [Hungarian]

[3] Esposito K, Giugliano F, Ciotola M, et al. Obesity and sexual dysfunction, male and female. Int J Impot Res. 2008; 20: 358365.

[4] Gerbild H, Larsen CM, Graugaard C, et al. Physical activity to improve erectile function: a systematic review of intervention studies. Sex Med. 2018; 6: 75-89. 
[5] Szigethy E, Széles G, Horváth A, et al. Epidemiology of the metabolic syndrome in Hungary. Public Health 2012; 126: 143149.

[6] Masquio DC, de Piano A, Campos RM, et al. The role of multicomponent therapy in the metabolic syndrome, inflammation and cardiovascular risk in obese adolescents. Br J Nutr. 2015; 113: 1920-1930

[7] DeBoer MD. Obesity, systemic inflammation, and increased risk for cardiovascular disease and diabetes among adolescents: a need for screening tools to target interventions. Nutrition 2013; 29: 379-386.

[8] Alvisi S, Baldassarre M, Lambertini M, et al. Sexuality and psychopathological aspects in premenopausal women with metabolic syndrome. J Sex Med. 2014; 11: 2020-2028.

[9] Baldassarre M, Alvisi S, Mancini I, et al. Impaired lipid profile is a risk factor for the development of sexual dysfunction in women. J Sex Med. 2016; 13: 46-54.

[10] Martelli V, Valisella S, Moscatiello S, et al. Prevalence of sexual dysfunction among postmenopausal women with and without metabolic syndrome. J Sex Med. 2012; 9: 434-441.

[11] Borges R, Temido P, Sousa L, et al. Metabolic syndrome and sexual (dys)function. J Sex Med. 2009; 6: 2958-2975.

[12] Simão AN, Lozovoy MA, Bahls LD, et al. Blood pressure decrease with ingestion of a soya product (kinako) or fish oil in women with the metabolic syndrome: role of adiponectin and nitric oxide. Br J Nutr. 2012; 108: 1435-1442.

[13] Maiorino MI, Bellastella G, Giugliano D, et al. From inflammation to sexual dysfunctions: a journey through diabetes, obesity, and metabolic syndrome. J Endocrinol Invest. 2018; 41: 12491258.

[14] Allen MS, Walter EE. Health-related lifestyle factors and sexual dysfunction: a meta-analysis of population-based research. J Sex Med. 2018; 15: 458-475.

[15] Alidu H, Owiredu WK, Amidu N, et al. Hypertension and obesity comorbidities increases coronary risk, affects domains of sexual function and sexual quality of life. Int J Impot Res. 2018; 30: 8-13.

[16] Kriston L, Günzler C, Agyemang A, et al., for the SPARK Study Group. Effect of sexual function on health-related quality of life mediated by depressive symptoms in cardiac rehabilitation. Findings of the SPARK project in 493 patients. J Sex Med. 2010; 7: 2044-2055.

[17] Byrne M, Doherty S, Murphy AW, et al. The CHARMS Study: cardiac patients' experiences of sexual problems following cardiac rehabilitation. Eur J Cardiovasc Nurs. 2013; 12: 558-566.

[18] Salonia A, Capogrosso P, Clementi MC, et al. Is erectile dysfunction a reliable indicator of general health status in men? Arab J Urol. 2013; 11: 203-211.

[19] Maseroli E, Scavello I, Vignozzi L. Cardiometabolic risk and female sexuality - Part I. Risk factors and potential pathophysiological underpinnings for female vasculogenic sexual dysfunction syndromes. Sex Med Rev. 2018; 6: 508-524.

[20] Polland A, Davis M, Zeymo A, et al. Comparison of correlated comorbidities in male and female sexual dysfunction: findings from the third national survey of sexual attitudes and lifestyles (Natsal-3). J Sex Med. 2018; 15: 678-686.

[21] Kizilay F, Gali HE, Serefoglu EC. Diabetes and sexuality. Sex Med Rev. 2017; 5: 45-51.

[22] Dyck PJ, Albers JW, Andersen H, et al., on behalf of The Toronto Expert Panel on Diabetic Neuropathy. Diabetic polyneuropathies: update on research definition, diagnostic criteria and estimation of severity. Diabetes Metab Res Rev. 2011; 27: 620628
[23] Dyck PJ, O'Brien PC, Litchy WJ, et al. Monotonicity of nerve tests in diabetes: subclinical nerve dysfunction precedes diagnosis of polyneuropathy. Diabetes Care 2005; 28: 2192-2200.

[24] Hotaling JM, Sarma AV, Patel DP, et al., for the DCCT/EDIC Research Group. Cardiovascular autonomic neuropathy, sexual dysfunction, and urinary incontinence in women with type 1 diabetes. Diabetes Care 2016; 39: 1587-1593.

[25] Tafazoli M, Parnan A, Azmoude E. Sexual function and quality of life in diabetic women referring to health care centers in Mashhad. J Educ Health Promot. 2017; 6: 25.

[26] Pop-Busui R, Hotaling J, Braffett BH, et al., for the DCCT/ EDIC Research Group. Cardiovascular autonomic neuropathy, erectile dysfunction and lower urinary tract symptoms in men with type 1 diabetes. J Urol. 2015; 193: 2045-2051.

[27] Wessells H, Penson DF, Cleary P, et al. for the DCCT/EDIC Research Group. Effect of intensive glycemic therapy on erectile function in men with type 1 diabetes. J Urol. 2011; 185: 18281834.

[28] De Berardis G, Pellegrini F, Franciosi M, et al., QuED Study Group. Clinical and psychological predictors of incidence of selfreported erectile dysfunction in patients with type 2 diabetes. J Urol. 2007; 177: 252-257.

[29] López-Jaramillo P, Gómez-Arbeláez D, López-López J, et al. The role of leptin/adiponectin ratio in metabolic syndrome and diabetes. Horm Mol Biol Clin Investig. 2014; 18: 37-45

[30] Pontiroli AE, Cortelazzi D, Morabito A. Female sexual dysfunction and diabetes: a systematic review and meta-analysis. J Sex Med. 2013; 10: 1044-1051.

[31] Gorgel SN, Gorgel A, Sefik E. Sexual function in male patients with metabolic syndrome and effective parameters on erectile dysfunction. Int Braz J Urol. 2014; 40: 56-61.

[32] Yaylali GF, Tekekoglu S, Akin F. Sexual dysfunction in obese and overweight women. Int J Impot Res. 2010; 22: 220-226.

[33] Mozafari M, Khajavikhan J, Jaafarpour M, et al. Association of body weight and female sexual dysfunction: a case control study. Iran Red Crescent Med J. 2015; 17: e24685.

[34] Tan WS, Ng CJ, Khoo EM, et al. The triad of erectile dysfunction, testosterone deficiency syndrome and metabolic syndrome: findings from a multi-ethnic Asian men study (The Subang Men's Health Study). Aging Male 2011; 14: 231-236.

[35] Chao JK, Kuo WH, Chiang HS, et al. Association of metabolic syndrome, atherosclerosis risk factors, sex hormones in ED in aboriginal Taiwanese. Int J Impot Res. 2012; 24: 141-146.

[36] Schipilliti M, Caretta N, Palego P, et al. Metabolic syndrome and erectile dysfunction: the ultrasound evaluation of cavernosal atherosclerosis. Diabetes Care 2011; 34: 1875-1877.

[37] Gokkaya CS, Aktas BK, Toprak U, et al. Is there a concordance between carotid and penile cavernosal artery intima-media thickness in patients with erectile dysfunction? Int J Impot Res. 2012; 24: 44-48

[38] Montorsi P, Ravagnani PM, Galli S, et al. The artery size hypothesis: a macrovascular link between erectile dysfunction and coronary artery disease. Am J Cardiol. 2005; 96(12 Suppl 2): 19-23.

[39] Canguven O, Talib RA, El Ansari W, et al. Vitamin D treatment improves levels of sexual hormones, metabolic parameters and erectile function in middle-aged vitamin D deficient men. Aging Male 2017; 20: 9-16.

[40] Otunctemur A, Dursun M, Ozbek E, et al. Effect of metabolic syndrome on sexual function in pre- and postmenopausal women. J Sex Marital Ther. 2015; 41: 440-449.

[41] Shifren JL, Monz BU, Russo PA, et al. Sexual problems and distress in United States women: prevalence and correlates. Obstet Gynecol. 2008; 112: 970-978.

[42] Chedraui P, Pérez-López FR, Blümel JE, et al. Hyperglycemia in postmenopausal women screened for the metabolic syndrome is 
associated to increased sexual complaints. Gynecol Endocrinol. 2010; 26: 86-92.

[43] Maseroli E, Fanni E, Cipriani S, et al. Cardiometabolic risk and female sexuality: focus on clitoral vascular resistance. J Sex Med. 2016; 13: 1651-1661.

[44] Morotti E, Battaglia B, Paradisi R, et al. Body mass index, Stunkard Figure Rating Scale, and sexuality in young Italian women a pilot study. J Sex Med. 2013; 10: 1034-1043.

[45] Trompeter SE, Bettencourt R, Barrett-Connor E. Metabolic syndrome and sexual function in postmenopausal women. Am J Med. 2016; 129: 1270-1277.
[46] Johannes CB, Clayton AH, Odom DM, et al. Distressing sexual problems in United States women revisited: prevalence after accounting for depression. J Clin Psychiatry 2009; 70: 1698706 .

(Pajor Attila dr., Budapest, Üllői út 78/A, 1082 e-mail: pajor.attilak@gmail.com)

\section{PÁLYÁZAT}

A Prof. Dr. Romics László Akadémikus Emlékére Alapítvány pályázatot hirdet Magyarországon dolgozó, magyar állampolgárságú, 40 éven aluli orvosok és orvosbiológiai kutatással foglalkozó személyek számára. A nyertes pályázó(k) között 500000 Ft alapítványi adomány kerül kiosztásra.

A pályázat célja: a klinikai gyógyítás vagy orvosi tudományos kutatás területén dolgozók kiemelkedő tudományos tevékenységének elismerése.

Előnyt élveznek azok a pályázók, akik az alapítvány névadójának munkásságát folytatva cardiovascularis és anyagcsere-betegségek területéről nyújtanak be pályázatot.

A pályázat benyújtásának határideje: 2019. január 31. (elbírálásának határideje: 2019. április 30.)

A pályázatot a palyazat@romicsalapitvany.hu e-mail címre pdf formátumban kell benyújtani.

A pályázatot természetes személy, saját nevében, magyar nyelven nyújthatja be, a pályázati anyag ábrák nélkül maximum 15000 leütés (karakter) terjedelmü lehet. A pályázathoz mellékelni kell egy rövid szakmai életrajzot a születési év megjelölésével.

A pályázat benyújtását saját kézzel aláírt és dátummal ellátott levélben kell bejelenteni az alapítvány titkárának címezve (a borítékra írandó cím: dr. Dudás Márta, 1461 Budapest, Pf 62.) könyvelt (ajánlott) küldeményben, mert ezen bejelentés alapján válik hitelessé a pályázat. A pályázatot nyomtatott formában nem kell mellékelni.

Az alapítvány adatairól, működéséről a www.romicsalapitvany.hu honlapon található információ.

A cikk a Creative Commons Attribution 4.0 International License (https://creativecommons.org/licenses/by/4.0/) feltételei szerint publikált Open Access közlemény, melynek szellemében a cikk bármilyen médiumban szabadon felhasználható, megosztható és újraközölhetö, feltéve, hogy az eredeti szerző és a közlés helye, illetve a CC License linkje és az esetlegesen végrehajtott módosítások feltüntetésre kerülnek. (SID_1) 